\title{
THE EMERGENCE OF INTERNATIONAL LAW
}

\author{
Galina B. Vlasova, ${ }^{1}$ Vasily I. Vlasov, ${ }^{2}$ Svetlana V. Denisenko ${ }^{3}$
}

\begin{abstract}
The emergence of international law and periodization of its development remain relevant today. In general, most scientists consider that there were limited manifestations of international law in the era of Antiquity and the European Middle Ages. However, the manifestations that did emerge are significant. In particular, the practice of settling interstate agreements in the Ancient East evidences such importance. In the context of ancient civilization, this practice reached a new level. It led to the emergence of sufficiently broad alliances of states and at the same time, customary international law, as was observed in the international legal practices in the times of Hellenistic era and the era of the Roman Empire.
\end{abstract}

UDC Classification: 341.7; DOI: http://dx.doi.org/10.12955/cbup.v6.1259

Keywords: periodization, practice of international agreement, military-political Union, international custom.

\section{Introduction}

The emergence of international law and its initial development refers to the era of the Ancient World and has received limited coverage in the arena of both foreign and domestic legal science. In the general history of law, international legal issues have had little focus apart from the few monographs on this subject. As a result, the study of such an important source of law as normative contractual content has suffered.

Nevertheless, the practice of settling interstate agreements has been widely developed in the Middle East during the Antiquity era. In addition, an intensive development of international law was observed in the Ancient World. Hence, the international legal practice during the era of classical Greece, Hellenism, the Roman Republic, and the Roman Empire are of interest since they present the foundations of the international law developed in modern times.

\section{The Periodization of International Law History}

Although it is an integral part of all human history, the history of international law appears incomplete. Historians have mainly focused on the law history of individual countries and states and no single conceptual approach for understanding the emergence and development of international law exists. Hence, the fundamental issue of when international law emerged remains unsolved. Some historians consider that international law began to develop in the context of inter-tribal relations (Batychko, 2011). Some associate it with the emergence of the first states. (Grabar, 1964; Phillipson, 1911). Others argue that international law appeared at the end of the Thirty-Year War (1618-1648) and with the occurrence of the Westphalian system of international relations (Butkevich, 2008).

International law appears to have emerged due to need in conditions to develop international relations. That is, international relations reached a level where independent states realized they needed to succumb to certain legal norms. Moreover, this action would have been important for the national interests of the states. Therefore, in parts of the world's history, it may be possible to observe how the law regulated the interstate relations.

Certainly, the conditions of modern times frame the continued use of international law.

In view of the above, the periodization of international law history is presented as follows:

- The prehistory of international law (Antiquity and the European Middle Ages);

- Classical international law (1648-1919);

- The transition from classical to the modern international law (1919-1945); and

- Modern international law (1945 to present).

\section{The Emergence of the First International Treaties in the Ancient East}

The first known documents of international law are from the age of the Ancient World. The history of this era begins in the East where the international law of ancient despotic monarchies was in the initial

\footnotetext{
${ }^{1}$ Department of Theory and History of State and Law, Rostov State University of Economics (RSUE), Rostovon-Don, Russia, vlasovagb@mail.ru

${ }^{2}$ Department of History of the Theory of Law and State, Russian State University of Justice, Rostov branch, Rostov-on-Don, vlasovvi@mail.ru

${ }^{3}$ Russian State University of Justice. Rostovbranch. Rostov-on-Don, s.v.denisenko@bk.ru
} 
stage. However, various historical sources have mentioned international treaties at this time. In general, the law of force prevailed and all conflicts were resolved through war. Some states defeated others. As a result, major powers, such as the Assyrian Empire, the new Babylon Kingdom, the Persian Empire, the Mauryan Power, and the Chinese Empire, were created and destroyed.

Of particular interest is the history of relations between Egypt's Pharaohs of the 19th dynasty and the Kingdom of the Hittites. In 1290 BC, Ramses II ascended the Egyptian throne and ruled for 67 years. During this reign, the Egyptian kingdom controlled the entire valley of the Nile River and established itself in Palestine. In southern Syria, Egyptian troops started a war with the Hittites. Outcomes of this conflict included the El-Amarna Correspondence and the peace agreement between the Pharaoh, Ramses II, and Hittite's King, Hattušili III, in 1276 BC. It was the first known peace treaty and the oldest document of international law.

The initiative for peace and the amicable agreement came from the Hittite king. After long preliminary negotiations, Hattušili III sent Ramses the draft agreement, which had been written on a silver plaque. There was an image of the king standing next to the god of wind and lightning, Teshub, on the front of the plaque to certify the authenticity of the document. The queen and the sun goddess, Arinna, stood together on the reverse side of the plaque.

Ramses accepted the conditions of peace, which had been offered to him by the Hittite king and sent Hattušili III another silver plaque with the text of the peace agreement. Both versions were affixed with state seals and signatures. Three original versions of the treaty are preserved. Two originals were found in Egypt with one found at Karnak Temple and another at the Ramesseum. Another version was found at Hattusa, the Hittite capital. Both, the text of the treaty and the descriptions of the pre-treaty negotiations survived. The agreement consists of three parts: the introduction, the text of clauses, and the conclusion, which contained an address to the gods, oaths, and curses against the violator of the agreement.

The introduction states that for a long time the Hittites and the Egyptians were allies. The relations between them deteriorated during the reign of Hattušili III's brother, who began the war against Ramses, the great king of Egypt. When the 'fine contract' was signed, the two kingdoms came to live in peace and harmony for enduring times.

After I have become a king of the Hittites, the great king of Egypt Ramses and I are in peace and brotherhood. It will be the best peace and brotherhood that has ever existed on Earth....Let it be a wonderful peace and brotherhood among the children of the children of the great king of the Hittites and Ramses, the great king of Egypt. Egypt and the land of the Hittites will live in peace and brotherhood for all time. (Langdon and Gardiner, p.180)

The amicable defensive and offensive alliance was agreed between the Hittites and Egypt. "If some enemy goes against the land of Ramses, he will say to the great king of the Hittites, come with me against him with all your powers" (Reading-book, 1997, p. 22). According to the agreement, the sides were to support each other against the enemy, not only from the outside but also from the inside. The allies guaranteed each other assistance in the event of uprisings and insurgencies in the controlled areas. It concerned mainly Asiatic (Syro-Palestinian) areas and failed to stop the war, rebellion, bandit raids, and lootings.

According to Thompson (1963, p. 27), the treaty states: "If Ramses is angry with his slaves (Asian citizens) when they rebel, and he goes to pacify them, King Hittites must act the same." A special article provided for mutual extradition of political defectors of noble and unfamiliar origin: "If someone escapes Egypt and goes to the land of the Hittites, the king of the Hittites will not detain him in his country, and he will return him to Ramses" (Thompson, 1963, p.28). All his property and his people are also returned. "If one, two, three, etc. men escape from the Egyptian land to the land of the Hittites, they must be returned to the land of Ramses" (Thompson, 1963, p.28). Their property, wives, children, and servants return in full safety. "They won't be executed, and won't be hurted their eyes, mouth and feet" (Thompson, 1963, p. 29). Witnesses of fidelity and accuracy of the contract are the gods and goddesses of both countries. "Everything that is inscribed on the silver board, a thousand gods and goddesses of the Hittite land undertake to fulfill in relation to a thousand gods and goddesses of Egypt. They are witnesses of my words" (Thompson, 1963, p.29). Then a long list of Egyptian and Hittite gods follows: "the gods and goddesses of the mountains and rivers of the country of Egypt, of 
heaven and earth, the sea, wind and storms" (Thompson, 1963, p.30). A terrible punishment follows for breach of contract. The gods will give health and prosperity for the honesty in its implementation. "Let disappear the house, the land, and the slaves of him who break these words be cast away. Let there be health and life for him, the land and the slaves of him who keep them" (Thompson, 1963, p.30). The exchange of diplomatic letters and embassies continued after the 'fine contract' was signed. The queens of both kingdoms also exchanged the letters. The Egyptian and Hittite queens expressed joy to each other because of the 'fine contract' and 'great brotherhood' that had developed between the two powerful despots.

Therefore, the Egyptian-Hittite agreement, which existed more than three thousand years ago, was a prototype for modern international agreements.

\section{The Emergence of International Law in the Ancient World}

The practice of settling international agreements was further developed in Ancient Greece. All political agreements directly or indirectly concluded between the Greek tribes and city-states were approved by the Delphic priests. The parties appealed to Delphi on all controversial issues of international law. The power of the priests was not only in their spiritual guidance but also in their material influence. Delphi had a huge capital. A special type of international law in Ancient Greece involved the agreements based on military and political alliances (symmahia). The most significant of which were the Lacedaemonian and the Athenian alliances.

The Lacedaemonian alliance was founded in the 6th century $\mathrm{BC}$ as the union of towns and communities of the Peloponnese. Sparta was the head of the union. The supreme union body was the all-union assembly (syllogos), which was convened by the city-hegemonic (Sparta) once a year. All cities that were part of the union had only one vote, despite of their size and importance. The cases were resolved by a majority vote, after a long debate and various diplomatic combinations.

Another major union of the Hellenic cities was the Delian League (symmahia), led by Athens. This Delos alliance (symmahia) was formed during the Greco-Persian wars as a union against the Persians. The Delos alliance had two characteristics that differed from the Lacedemonian alliance. First, its allies contributed a special payment (Phoros) to the public treasury of Delos. Second, they depended on the hegemony of Athens. Later, the Delos alliance became the Athenian power (Arche).

Relations between the two alliances were inhospitable from the beginning and by the 5th century, the situation led to the Panhellenic Peloponnesian war.

In $448 \mathrm{BC}$, the head of the Athenian state, Pericles, proposed to convene the Panhellenic (Greek) Congress in Athens. Three issues, which concerned all Greeks, had to be resolved by the Congress: the restoration of churches that were destroyed by Persians, free navigation, and the consolidation of peace in all of Hellas. At the same time, Pericles hoped to promote the transformation of Athens into a political and cultural center for all of Greece.

For this project, an embassy of 20 people from Athens was sent to all Greek cities with an invitation to send representatives to the future Congress. The deputation was divided into four parts. Some went to the cities and Islands of Asia minor; others went to the banks of the Hellespont and Thrace; others to Beotia and Fokida; and others to the Peloponnese. The Athenian ambassadors urged citizens of each city to accept the invitation to the Congress in Athens. Pericles' proposal did not receive a response. Especially strong resistance was provided by Peloponnese because of the fear that Athens would become more powerful.

After the Peloponnesian war, some armed conflicts between the Greek city-states occurred. Incorporating their differences, in 387 BC, King Artaxerxes II of Persia proposed to the Greeks a peace agreement, known in history as the Peace of Antalcidas, named after a Spartan diplomat. This agreement secured the Greek city-states of Asia Minor for Persia and the Islands of Clazomenae and Cyprus. It also banned the organization of some unions in Greece, apart from the Peloponnese, which had no effective power, and finally secured the politically fragmented Greece. The power of Sparta was completely undermined. However, the Macedonian Kingdom increased in the North of the Balkan Peninsula by the 4th century BC. King Philip II of Macedon defeated the opponents of Macedonia in Greece and convened a general Greek meeting in Corinth of the Sanhedrin in 338 BC where universal peace in Greece was proclaimed. The Greek fragmentation was overcome. The Macedonian king 
created the Greek federation and was elected as the hegemon. All members of the federation settled on a defensive and offensive alliance.

In 336 BC, Philip II was assassinated and his son, Alexander the Great (Macedonian), realized his plans by conquering and governing the entire Persian Empire from Egypt to India for 10 years. A new period of ancient history, the period of Hellenism, arose after the death of Alexander the Great. Within the Hellenistic states, there was a synthesis of Ancient and Asian (Eastern) social systems. In the history of the Ancient World, there had never before been as many allied treaties. The preserved texts of treaties and letters of rulers are the monuments of international law of the Hellenistic era. A typical example is an agreement between Carthage and Macedonia that was signed in $215 \mathrm{BC}$.

As a general rule, the contract began with vows and promises to stay in mutual friendship, brotherhood, and eternal loyalty. Hannibal, the commander-in-chief of the Carthage army, on the one hand, and the Macedonian king Philip V, on the other, vowed to remain in alliance for eternity.

The text of the agreement followed the introduction. According to Phillipson (1911, p.45), the Macedonians and the Carthaginians made a defensive and offensive Alliance: "We Macedonians must be enemies to the Carthaginians' enemies." The same words were repeated by the Carthaginians. The agreement, first of all, provided mutual assistance of the parties in the war with Rome. "If the Romans start the war against us or against you, we will help each other....You Macedonians will be our allies in the war until the gods grant us and you total victory." (Phillipson, 1911, p.52)

It was further declared that the Union of Carthage and Macedonia was a firm guarantee of peace and sustainability of international relations.

In the context of Hellenism, the exchange of embassies was frequent and certain standards of conduct were developed during international negotiations. It was the era of Hellenism when international customs were a source of international law. Their violation was perceived as savagery.

According to international customs, it was impossible to use poisoned weapons in war. In addition, prisoners of war had to be returned where a ransom was offered and neighbors could not be attacked without an official declaration of war. It was crucial to show neighboring countries that a state that breached the peace and started a war was forced to abide by these rules. The war was the last means where negotiations failed to produce results.

Certain steps in the development of international law were also formed in Ancient Rome. The procedures for declaring war and concluding peace were elaborated upon and retained, as in the Hellenistic States. The rudiments of international law had already existed in the early Roman law. When the economic life becomes more difficult and peaceful relations with neighbors develop, the 'rights of people' (jus gentium) emerge. The international law regulated socioeconomic relations between the Roman and the foreigners (Grabar, 1964).

At the same time, the international law of the Roman Empire barely differed from the international law of the Roman Republic. In particular, the Embassy Law showed no change. The identity of the ambassador, as well as the hostile States, was sacred and inviolable, while the violation of embassy rights was considered a violation of international law.

Regarding the law of treaties, the contacts between Rome and Persia are important. Extant treaties and descriptions of the order of negotiations during the 3rd-4th centuries AD show the strong influence of Eastern customs. The external influence, which included various types of formalities and court ceremonies, complicated the outcome corresponding to the customs of the late Roman Empire.

\section{Conclusion}

This study of the phenomenon of international law emergence was based on the analysis of international agreements of the ancient Eastern despots and the Ancient World era. The results obtained from historical legal analysis indicates that the Egyptian way of remotely receiving a contract is a prototype for the latest international consolation. The development of international law in the Antiquity era occurred in two directions. First, it created large interstate Unions on the basis of treaties, and second, it developed international legal customs, which placed the development of relations between the states in certain civilized frameworks. Furthermore, it is important to note that these were the first steps in the development of international law, which was later acknowledged in the era of the Renaissance. 


\section{Acknowledgment}

This paper was undertaken as a part of the monographic studies 'History of domestic and international law.'

\section{References}

Batychko V.T. (2011). International law. Lecture course, Taganrog, SFEDU publ.

Butkevich O. V. (2008). The promotion of international law -SPb: Publishing house R Aslanova "Legal center Press". P.148223. ISBN 978-5-94201-503-1.

Grabar.V.E. (1964). Personal importance of risky terminal jusgentium / / "Scientific notes Tartusky state University". Vol.148. P.21-28.

Langdon S., Gardiner A. (1920). The Treaty of Alliance between Hattušili, King of the Hittites, and the Pharaoh Ramesses II of Egypt. The Journal of Egyptian Archaeology, Vol. 6, No. 3, pp. 179-205.

Reading-book on History of Ancient East. M. P.18-26.

Phillipson C. (1911). The international law and customs in Ancient Greece and Rome. London, P.15-98.

Thompson J. A. (1963). Ancient near Eastern treaties and the old Testament. London, P.25-37. 